\title{
The Validity Of Lever Sign Test For The Diagnosis Of ACL Injury
}

\author{
By \\ Almohamady Algharib Saeed, Mohamed Abdelaziz Hassan, Emad \\ Mohamed Zayed and Mohamed Abdelhamid Assy \\ Department of Orthopedic Surgery, Faculty of Medicine, Al-Azhar University Cairo, \\ Egypt
}

\begin{abstract}
Background: Injury of the anterior cruciate ligament (ACL) is the most frequently seen ligamentous injury of the knee joint. Diagnosis is based on history, physical examination and MRI findings and a definitive diagnosis is confirmed with arthroscopy. Many tests are used for diagnosis of ACL with different sensitivity and specificity.
\end{abstract}

Objectives: To evaluate lever sign test as a diagnostic tool for ACL injury compared the other 3 tests (anterior drawer, Lachman, and pivot shift test) when performed before anesthesia and under anesthesia.

Patients and Methods: The study included 100 patients in the age of 18 to 45 years complaining of knee instability and confirmed as ACL injury by MRI. The 4 special tests for ACL (the Lachman, the anterior drawer, the pivot shift test and the lever sign test) were performed on the injured knee and the contralateral non-injured knee as a control both preanesthesia and under anesthesia. The results were compared to the arthroscopic findings.

Results: Lever sign test sensitivity is $72 \%$ on examination before anesthesia and $80 \%$ on examination under anesthesia with specificity 92\%. The most sensitive test Preanesthesia was the Lachman test $88 \%$ and postanesthesia was the pivot shift test $89 \%$. The most specefic test was highest for the pivot-shift test $100 \%$.

Conclusion: Lever sign test is a simple test which can be routinely used in evaluation of ACL function in both acute and chronic knee injury. The test is weak diagnostic tool in partial ACL injury as it uses pure translational displacement as its assessment method and does not assess the rotational component.

Key words: Anterior cruciate ligament; ACL; Lelli; Lever sign test.

\section{INTRODUCTION}

The anterior cruciate ligament (ACL) is one of the most commonly injured knee ligaments and is one cause of anterior knee instability (Jarbo et al., 2017). ACL ruptures occures in young and physically active population and could result in instability followed by, meniscal tears, and articular cartilage damage if not well treated (Makhmalbaf et al., 2013). In the clinical evaluation, the first and most important step of the patient history is the physical examination. Three basic tests are used in the physical examination from which different results may be obtained according to the sensitivity and specificity of each test. These are the Lachman, the 
anterior drawer and the pivot shift test (DeFranco and Back, 2009). Patients may be guarding due to pain and fear of subluxation. Concomitant injuries may obstruct the physical exam. In addition, partial ruptures may be harder to diagnose than complete ruptures due to the stability provided by the remaining fibers (Van Eck et al., 2013).

Lever Sign test a new clinical test for the diagnosis of ACL described by Alessandro Lelli in 2014 (Lelli et al., 2014). It has been claimed that this test is more valuable than the other 3 tests in both partial and complete lesions. In particular, it has been suggested that it could be applied effectively, regardless of the interval from trauma to examination. One potential advantage of this physical examination method is that rapid motions of the injured knee can be avoided, likely reducing the incidence for additional patient pain and resultant guarding (Deveci et al., 2015).

While arthroscopic visualization is the gold standard for diagnosing rupture of the ACL, magnetic resonance imaging (MRI) is a valid and noninvasive diagnostic method, with a specificity and sensitivity of 94-98\%. MRI could show not only ACL tear but also shows any other soft tissue or bone injuries (Makhmalbaf et al., 2013).

\section{PATIENTS AND METHODS}

This study included 100 patients presented to the outpatient clinic of ElHussien Hospital complaining of knee instability after trauma to the knee. The ACL injury is confirmed by X-ray and MRI with no other ligamentous injury (Figure 1). The 4 special tests for ACL (the Lachman, the anterior drawer, the pivot shift test and the lever sign test) were performed on the injured knee and the contralateral non-injured knee as a control both before anesthesia and under anesthesia.

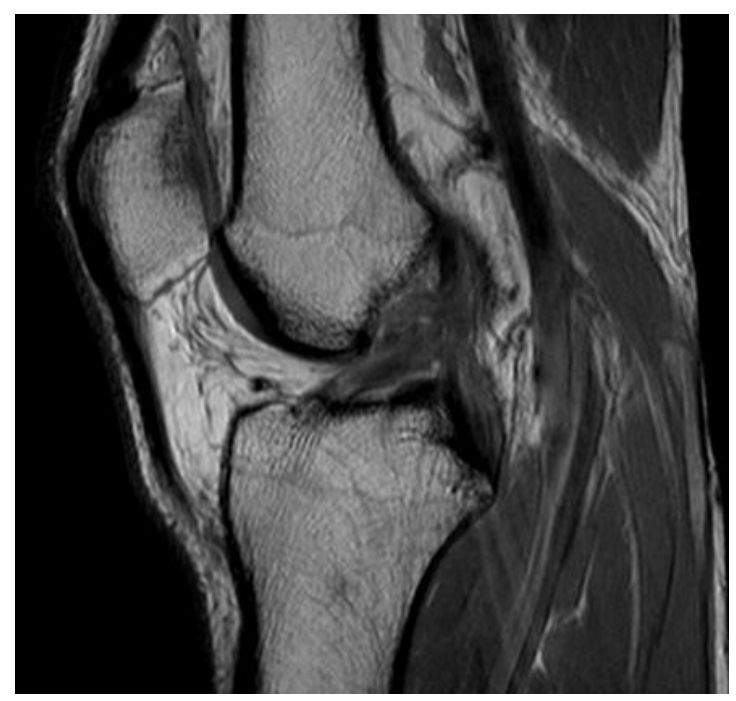

Figure (1): Sagittal T2- weighted magnetic resonance knee image shows abnormal signal of ACL suggest ACL tear.

The lever sign test was performed as described by Lelli; the patient is placed supine with the knees fully extended on a hard surface such as the examining table. The examiner stands at the side of the patient and places a closed fist under the proximal third of the calf. This causes the knee to flex slightly. With his other hand, he applies moderate downward force to the distal third of the quadriceps (Lelli et al., 2014).

In an intact knee, the creation of a complete lever by the ACL allows the downward force on the quadriceps to more than offset the force of gravity, the knee joint rotates into full extension, and the heel rises up off of the examination table (Lelli et al., 2014). 
In ACL deficient knee, tibial plateau slides anteriorly with respect to the femoral condyles. In this case, the gravity pulls the heel down to the examination table and the heel does not rise up off of the table (Prodromos et al., 2007). The results were compared to the arthroscopic finding as the gold standard for diagnosis of ACL injury (Figure $3 \& 4$ ).

According to arthroscopic findings, 82 of patients had complete ACL tear (82\%) and 18 patients had partial tear $(18 \%)$.
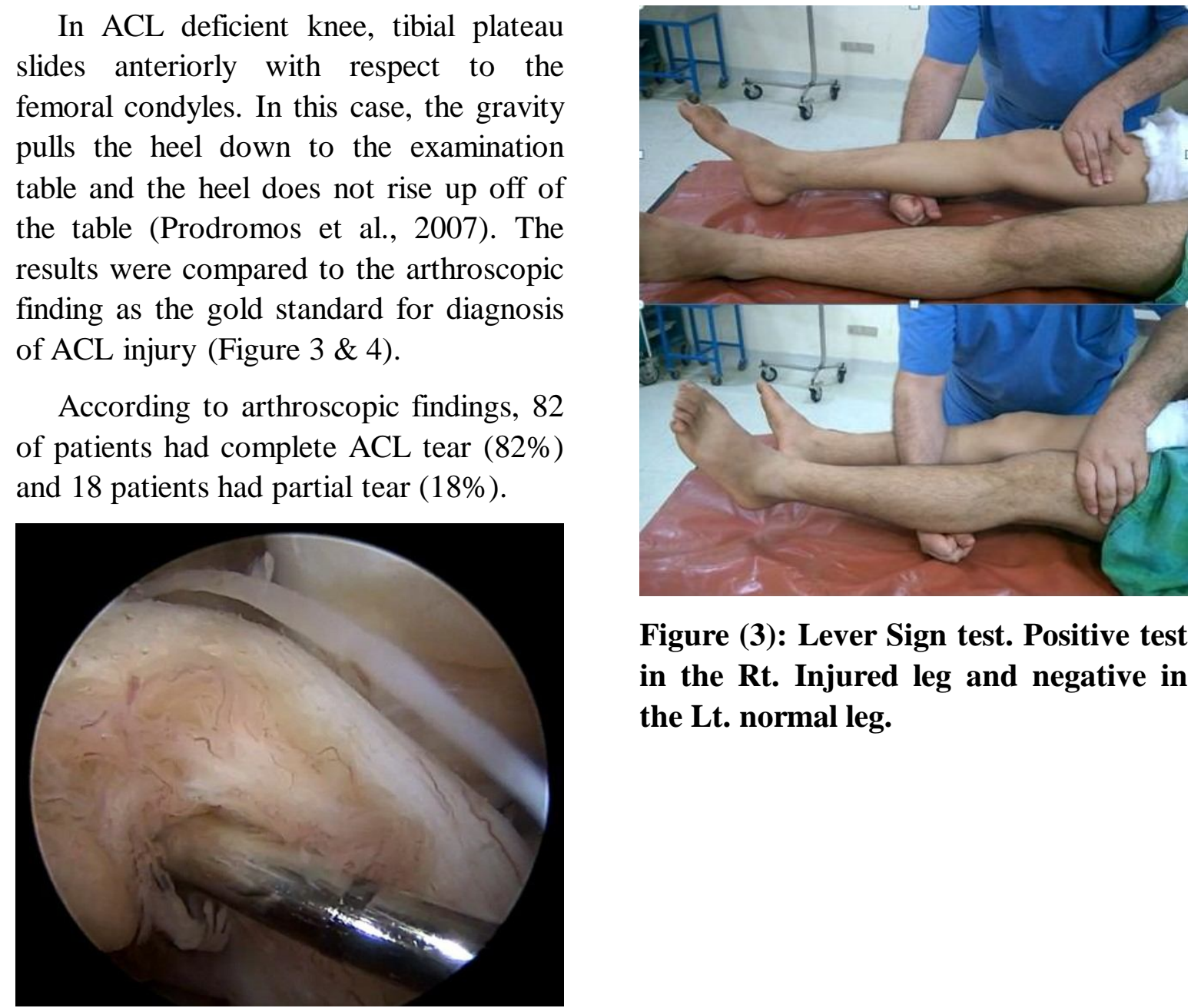

Figure (3): Lever Sign test. Positive test in the Rt. Injured leg and negative in the Lt. normal leg.

Figure (2): Arthroscopic view of knee joint showing remnant of torn ACL.

\section{RESULTS}

Preanesthesia and postanesthesia sensitivities were $88 \%$ and $96 \%$, respectively, for the Lachman test; $78 \%$ and $88 \%$, respectively, for the anterior drawer test; $54 \%$ and $98 \%$, respectively, for the pivot shift test; and $72 \%$ and $80 \%$, respectively, for the lever sign test. The specificity was highest for the pivot-shift test $100 \%$, followed by the Lachman test $96 \%$, anterior drawer test $92 \%$, and lever sign test $92 \%$ (Table 1).

Comparing the results of the lever sign test with the arthroscopic results , 78 patients had positive test of 82 patients with complete ACL tear $95 \%$ and 2 patients had positive test of 18 patients with partial ACL tear $11 \%$. 
Table (1): The sensitivity values of all 4 tests at preanesthesia and postanesthesia.

\begin{tabular}{|c|c|c|}
\hline & $\begin{array}{c}\text { Preanesthesia assessment } \\
(\%)\end{array}$ & $\begin{array}{c}\text { Postanesthesia assessment } \\
(\%)\end{array}$ \\
\hline Lachman test & 88.0 & 96.0 \\
\hline Anterior drawer test & 78.0 & 88.0 \\
\hline Pivot-shift test & 54.0 & 98.0 \\
\hline Lever sign test & 72.0 & 80.0 \\
\hline
\end{tabular}

\section{DISCUSSION}

Early recognition of pathological processes of the ACL is crucial to selecting the correct course of care to optimize outcomes (Jarbo et al., 2017). Diagnosis of ACL tear is made by a combined evaluation of the patient history, physical examination and MRI. Accurate diagnosis is made by interpretation of these 3 steps together. The diagnostic standard for ACL injuries is direct arthroscopic visualization, but the accepted reference standard is magnetic resonance imaging (MRI), with sensitivity and specificity ranging from $94 \%$ to $98 \%$ (Ng et al., 2011).

In the clinical evaluation and after taking patient history, three basic tests are used in the physical examination from which different results may be obtained according to the sensitivity and specificity of each test. These are the Lachman, the anterior drawer and the pivot shift test. The physical examination methods are indispensable as practical, cheap, noninvasive methods (DeFranco et al., 2009).
The accuracy of these examinations may be affected by patient factors such as swelling, pain, protective muscle action, and examiner experience. The maneuvers themselves can produce falsely normal results, particularly in patients with partial tears (Jarbo et al., 2017).

There are some difficulties on applying these tests. For Lachman test examiners with small hands and patients with a large thigh may affect test results. (Kuroda et al., 2016).

The anterior drawer test the hemarthrosis and reactive synovitis may preclude knee flexion to $90^{\circ}$, hindering the proper performance of the test, protective muscle action of the hamstrings secondary to joint pain provides a vector force opposite to the anterior translation of the tibia and the posterior horn of the medial meniscus becomes buttressed against the posterior most margin of the medial femoral condyle and may preclude anterior translation of the tibia. The pivot shift test patient with a chronic ACLdeficient knee is familiar with unpleasant phenomenon of pivoting and will show 
protective muscle action. The accuracy of a complex test maneuver such as the pivot shift test may increase with experience thus the pivot shift test has very high specificity and low sensitivity (Thapa et al., 2015).

A clinical test for the diagnosis of ACL rupture is described: the so-called "Lever Sign". It has been claimed that this test is more valuable than the other 3 tests in both partial and complete lesions. In particular, it has been suggested that it could be applied effectively, regardless of the interval from trauma to examination. The lever sign test did not rely on the strength of the examiner or the size of the patient; a provider with small hands can easily and effectively perform this test on a patient with a large leg, an advantage that no other test can offer. One potential advantage of this physical examination method is that rapid motions of the injured knee can be avoided, likely reducing the incidence for additional patient pain and resultant guarding (Lelli et al., 2014).

Our study included 100 patients with knee concerns after an injury. The four special tests for ACL were performed on the injured knee and the contralateral noninjured knee as a control both preanesthesia and under anesthesia. The results were compared to the MRI and the arthroscopic findings.

In 2014, Lelli and Colleagues were the first to describe and assess the lever sign. the lever sign test was performed with the other three tests on the injured leg and the contralateral non-injured leg of all 400 patients.

In 2015, Thapa and Colleagues included 80 patients with knee concerns after an injury. The four physical examination maneuvers were performed on all patients and compared with arthroscopic surgery, the diagnostic standard.

In 2015, Deveci and Colleagues included 117 patients with an arthroscopic diagnosis of a chronic ACL tear (further specified as complete or partial). All patients underwent the 4 clinical examination maneuvers both preoperatively and under anesthesia.

In 2017, Jarbo and Colleagues included 102 patients, 54 were surgical and 48 were nonsurgical. In the nonsurgical group, the four tests were performed during the initial clinic visit, and in the surgical group, the four tests were performed in the operating room with the patient under anesthesia.

In our study, preanesthesia and postanesthesia sensitivities were $88 \%$ and $96 \%$, respectively, for the Lachman test; $78 \%$ and $88 \%$, respectively, for the anterior drawer test; $54 \%$ and $98 \%$, respectively, for the pivot shift test; and $72 \%$ and $80 \%$, respectively, for the lever sign test. The specificity was highest for the pivot-shift test $100 \%$, followed by the Lachman test $96 \%$, anterior drawer test $92 \%$, and lever sign test $92 \%$.

Results of Lelli et al. (2014) were $100 \%$ sensitivity and $100 \%$ specificity for the lever sign test. Results of Thapa et al. (2015) were $86 \%$ sensitivity and $91 \%$ specificity. Results of Deveci et al. (2015) were $94 \%$ sensitivity preanesthesia and 98\% sensitivity postanesthesia. Jarbo et al. (2017) stated that were $68 \%$ sensitivity preanesthesia , $86 \%$ sensitivity postanesthesia and $90 \%$ specificity. 
After comparing data of the patients and results of all four tests, there was no statistically significant relation between patient's age, sex, or associated meniscal injury and the sensitivity of lever sign test.

\section{CONCLUSION}

Lever sign test being simple, with comparable sensitivity and specificity to those routinely applied clinical test for ACL tear can be routinely used in evaluation of ACL function in both acute and chronic knee injury.

The lever sign test, similar to the anterior drawer and Lachman tests, uses pure translational displacement as its assessment method and does not assess the rotational component, which may lead to a missed diagnosis in a partial tear. Additionally, the test is not affected by anesthesia, which cannot be stated for other ACL examinations as pivot shift test.

\section{REFERENCES}

1. DeFranco MJ and Bach BR (2009): A comprehensive review of partial anterior cruciate ligament tears. J Bone Joint Surg Am., 91(1):198-208.

2. Deveci A, Cankaya D, Yilmaz S, ? zdemir G, Arslantaş E and Bozkurt M. (2015): The arthroscopical and radiological corelation of lever sign test for the diagnosis of anterior cruciate ligament rupture. Springer plus, 4(1):830-41.

3. Jarbo KA, Hartigan DE, Scott KL, Patel KA and Chhabra A. (2017): Accuracy of the
Lever Sign Test in the Diagnosis of Anterior Cruciate Ligament Injuries. Orthopaedic Journal of Sports Medicine, 5(10):232-51.

4. Kuroda, R., Matsushita, T. and Araki, D. (2016): Physical Examinations and Device Measurements for ACL Deficiency. In ACL Injury and Its Treatment pp. 129-137.Pbi. Springer, Tokyo.

5. Lelli A, Di Turi RP, Spenciner DB and D?mini M. (2014): The Lever Sign: a new clinical test for the diagnosis of anterior cruciate ligament rupture. Knee Surgery, Sports Traumatology, Arthroscopy, 24(9):2794-7.

6. Makhmalbaf H, Moradi A, Ganji $S$ and Omidi-Kashani F. (2013): Accuracy of Lachman and anterior drawer tests for anterior cruciate ligament injuries. Archives of Bone and Joint Surgery, 1(2):94-117.

7. Ng WHA, Griffith JF, Hung EHY, Paunipagar B, Law BKY and Yung PSH. (2011): Imaging of the anterior cruciate ligament. World Journal of Orthopedics, $1 ; 2(8): 75-88$.

8. Thapa SS, Lamichhane AP and Mahara DP. (2015): Accuracy of Lelli test for anterior cruciate ligament tear. Journal of Institute of Medicine, 6;38(2):91-94.

9. Van Eck CF, van den Bekerom MP, Fu FH, Poolman RW and Kerkhoffs GM. (2013): Methods to diagnose acute anterior cruciate ligament rupture: a meta-analysis of physical examinations with and without anaesthesia. Knee Surgery, Sports Traumatology, Arthroscopy, 1;21(8):1895-903. 


\section{صلاحية إختبار الر افعة في تشخيص إصابة الرباط الصليبي الأمامي}

المحمدى الغريب سعيد - محمد عبد العزيز حسن - عماد محمد زايد - محمد عبد الحميل عاصي قسم جراحة العظام - كلية الطب - جامعة الأزهر

خلفيـة البحث : إصـابة الربـاط الصـليبي الأمـامي مـن أكثر الإصـابات في مفصـل الركبـة. و يعتمــ التشخيص على التاريخ و الفحص البدني ونتائج التصـوير بـالرنين المغناطيسي، ويتم تأكيد التشخيص النهائي بو اسـطة المنظـار ـ و يـتم اسـتخدام العديـد مـن الإختبـار ات لتشـخيص إصـابة الربـاط الصـليبي الأمامي مع إختلاف دقة وخصوصية كل إختبار.

الههف من البحث: تقييم إختبار الر افعه كأداة لتشخيص إصـابة الرباط الصليبي الأمسامي مقارنة بثلاثته اختبار ات أخرى (إختبـار الدرج الأمسامي ، و إختبار لاخمن ، وإختبـار التحول المحوري) عندما يتم التتفيذ قبل التخدير وتحت التخدير.

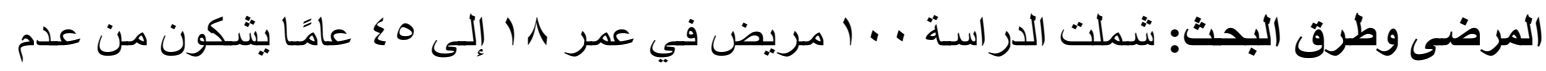
إستقر ار الركبة، و تم تأكيد إصابة الرباط الصليبي الأمسامي بواسطة التصوير بـالرنين المغناطبسي. و قد تم إجراء ء إختبار ات (إختبار الدرج الأمامي ، و إختبار لاخمن وإختبار التحول المحوري و إختبار الر افعـة) قبـل التخدير وتحت التخدير على الركبـة المصـابة و الركبـة المقابلـة غير المصـابة كمرجـع. وتمت مقارنة النتائج إلى نتائج المنظار.

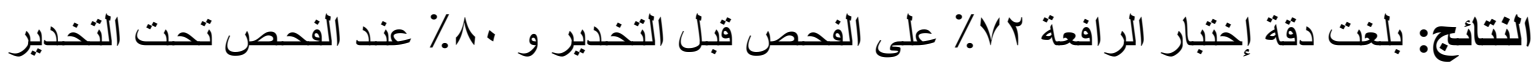

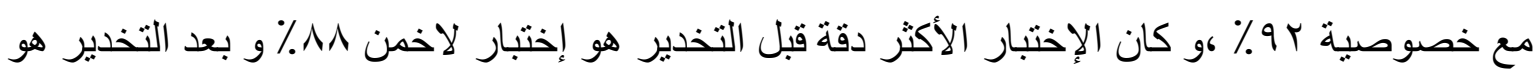
إختبار التحول المحوري 9 ٪ ٪و كان الإختبار الأكثر خصوصية هو إختبار التحول المحوري بنسبة $\%$. .

الاستتتاج: إختبـار الر افعـة هو اختبـار بسيط يمكن إستخدامه بشكل روتيني في تقييم وظيفـة الربـاط الصليبي الأمامي في إصابة الركبة الحادة والمزمنة و الإختبار هو أداة تشخيص ضـعيفة في الإصـابة الجزئيسة للربـاط الصـليبي حيث أنسه يستخدم الانتقال الأمسامي للقصبة كطريقة تقييمه، و لا يقوم بتقيميم مكون الدوران. 